\title{
A REVIEW OF BIORETENTION TECHNOLOGY: NEW ISSUES, CURRENT RESEARCHES, AND LIMITATIONS OF NITROGEN REMOVAL PROCESSES UNDER MULTIPLE DRYING- REWETTING ALTERNATIONS
}

\author{
ChEN, Y. $.^{{ }^{*}}-$ FEnG, L. K. ${ }^{1}-$ GAN, C. J. ${ }^{2}-$ YuAN, S. C..$^{{ }^{*}}$ \\ ${ }^{1}$ Key Laboratory of Hydraulic and Waterway Engineering of the Ministry of Education, School \\ of River and Ocean Engineering, Chongqing Jiaotong University, Chongqing 400074, China \\ (phone: +86-23-6265-2714; fax: +86-23-6265-0204) \\ ${ }^{2}$ Chongqing Municipal Research Institute of Design, Chongqing 400012, China \\ *Corresponding authors \\ e-mail: chenyao@cqjtu.edu.cn; yuansc@cqjtu.edu.cn \\ (Received $18^{\text {th }}$ Mar 2020; accepted 20 ${ }^{\text {th }}$ Aug 2020)
}

\begin{abstract}
Bioretention technology has become an optimal tool in restorative stormwater management. However, the performance of nitrogen removal lacks good stability in adapting to environmental changes and responding to natural disasters. More specifically, nitrogen leaching is an important problem to be solved under multiple drying-rewetting alternations. Focusing on processes of nitrogen removal in multimedia, the purpose of this manuscript is to summarize the new issues of bioretention system controlling nitrogen, and to elucidate the processes of nitrogen removal from three aspects, including influence of multiple drying-rewetting alternations, characterization of nitrogen process in different spatiotemporal scales and contribution of multi-media. We suggest that future studies of bioretention technology should focus on the explanation of nitrogen leaching mechanism. Wherein, the coupling response relationship between processes of the nitrogen removal is a key issue. To understand this relationship, the quantitative contribution of multi-media to fate and transport of nitrogen, community structure of functional microbes, and microbial metabolic characteristics to nitrogen under multiple drying-rewetting alternations should be studied.
\end{abstract}

Keywords: stormwater, bioretention, multi-media, nitrogen, leaching, fate and transport, functional bacteria

\section{Introduction}

Urbanization leads to an increase in impervious surfaces (paved roadways, parking lots, sidewalks, and roof tops), thus decreasing the potential infiltration and evapotranspiration of precipitation, and reducing base flow. These results in accelerated and magnified surficial runoff from urban catchments, a higher intensity of flooding, increased stream bank erosion, and habitat fragmentation and loss (Olang and Fürst, 2011; Rhea et al., 2015). Meanwhile, stormwater runoff also transports pollutants and nutrients from corresponding urban landscapes. Furthermore, elevated levels of contaminants in urban runoff are adverse to the ecological health of urban streams and receiving waters (Qin et al., 2013), collectively referred to as the "urban stream syndrome" (Walsh et al., 
2005). With the continuous expansion of urban populations and urban land cover, these issues will continue to be so in the foreseeable future.

Over past decades, more and more hydraulically efficient drainage infrastructures, termed as the "drainage efficiency" approach, have been used in urban areas for flood mitigation. In practice, however, these approaches proved to be insufficient due to the limited capacity of drainage systems (Mitchell, 2006; Fletcher et al., 2014). Besides, many attempts to mitigate hydrological impacts of urbanization have been characterized by a focus on peak flows. Although stormwater management is essential to alleviate flooding, but above all, it should reduce in-stream erosion pressure, limit nutrient loads in estuaries, and improve stream benthic health. Full recognition of the negative impacts of such an approach to stormwater drainage on water quality and flow regimes reached a consensus (Fletcher et al., 2014), which leads to a more integrated approach to stormwater management, incorporating water quality treatment and mitigating hydrological changes. In a shift away from past peak flow-centric controls, many novel stormwater control measures (SCMs) (e.g. green roofs, permeable pavements, wetlands, ponds, and bioretention systems) are being emphasized and implemented with decentralized systems widely to mitigate the hydrologic impact of large tracts of impervious surface. These SCMs that base on the concept of low impact development (also known as sustainable urban drainage systems, green infrastructure or water sensitive urban design) aim to maintain a natural site water balance through hydrological landscapes, and reach a return to "predevelopment hydrology". These decentralized measures have been recommended as an innovative solution for restorative stormwater management (Andoh and Declerck, 1997; Montalto et al., 2007; Palhegyi, 2010).

An effective SCM is bioretention, which is achieved by utilizing an engineered system containing a surface ponding layer, vegetation, a soil layer, a storage layer, overflow structures, and an optional underdrain system, depending on the surrounding soil characteristics (Liu et al., 2014). Bioretention (also called biofiltration systems, biofilters, or rain gardens) is increasingly used as a runoff management practice in urbanized areas. This technology has demonstrated excellent performance for reducing the concentrations and loads of pollutants in protection of waterways from polluted urban runoffs (Hatt et al., 2008; Hunt et al., 2008; Roy-Poirier et al., 2010; Debusk and Wynn Thompson, 2011; Liu et al., 2014; Lucke and Nichols, 2015). Furthermore, it can modulate peak flow through on-site retention of storm water with hydraulic capacity (Li et al., 2009; RoyPoirier et al., 2010; Trowsdale and Simcock, 2011; Debusk and Wynn Thompson, 2011; Ahiablame et al., 2012; Davis et al., 2012; Liu et al., 2014). And bioretention may exist in many different forms, such as rain gardens, swales, or infiltration cells (Laurenson et al., 2013).

Similar as other stormwater treatment facilities, bioretention systems experience high levels of variability in the frequency and period of inundation and intervening dry period. While performance evaluation of bioretention system has mainly remained on actual rainfall events, with little consideration taken to their inter-event (dry weather) behavior. 
Researchers using both field and laboratory scale studies have assessed the performance of bioretention systems highlighting the effect of drying-rewetting shifts on nitrogen removal processes. Alarmingly, some results showed that because of the frequency of drying-rewetting alternations bioretention systems not only fail to remove incoming nitrogen, but can leach additional nitrogen, such as nitrate-nitrogen $\left(\mathrm{NO}_{3}-\mathrm{N}\right)$ (Cho et al., 2011; Brown et al., 2013; Li and Davis, 2014; Mullane et al., 2015; Mangangka et al., 2015; Chahal et al., 2016; Manka et al., 2016; Wang et al., 2017, 2018; McPhillips et al., 2018; Shrestha et al., 2018), dissolved organic nitrogen (Blecken et al., 2010; Li and Davis, 2014; McPhillips et al., 2018; Shrestha et al., 2018), total Kjeldahl nitrogen (TKN) or total nitrogen (TN) (Blecken et al., 2010; Géhéniau et al., 2014; Mangangka et al., 2015; Mullane et al., 2015; Chahal et al., 2016; Wang et al., 2017; Poor et al., 2018; Shrestha et al., 2018). Thereby, the effluent nitrogen amounts were even elevated up to several orders of magnitude in the leachate compared to the stormwater itself (Payne et al., 2014c; Mangangka et al., 2015; Wang et al., 2017; Poor et al., 2018). Such a solubility and bioavailability of nitrogen flush in discharges could have significant ecological consequences, particularly for small waterways with limited buffering capacity. Unfortunately, to the best of our knowledge, the effect of variable rewetting/drying conditions on underlying nitrogen removal processes and the causes of nitrogen leaching in biorentention systems has been mostly unknown (LeFevre et al., 2014; Payne et al., 2014c). Restorative stormwater management requires the SCMs to adapt to changing climates and to protect the natural water ecologically sensitive areas to the utmost. Especially, it should achieve the protection (or remediation) of urban rivers, lakes and other aquatic ecosystems. Well, in which case, bioretention facilities located in urban areas should have good climate adaptability to control nitrogen in runoff effectively, and ultimately avoid the eutrophication in waters. More than 30 pilot cities in China are promoting the idea of the "sponge city" ( $\mathrm{Li}$ et al., 2017). It has been found that biorentention technology is the choice for the preferential practices. Consequently, we can conclude that how to remove nitrogen efficiently and steadily is a fundamental issue for sponge city research in China. Meanwhile, the adapting ability of bioretention technology under changing conditions should also be urgently improved to achieve water quality standards in stormwater management. However, the existing theory, methods and measures related to bioretention technology cannot realize the climate adaptability of nitrogen process.

The main objective of this study is to develop a new knowledge relating to nitrogen multi-media process containing plant, soil and microorganism. Firstly, we discussed the unique issues faced in the nitrogen control of the bioretention system. Secondly, the limitation of nitrogen process was summarized and discussed from the following aspects: (1) the effects of multiple alternating wet and dry processes on the nitrogen process; (2) the characterization of nitrogen processes at different spatial and temporal scales; and (3) nitrogen partitioning and transport in multi-media. In this review, we aim to provide important insights and recommendations for future research on the processes of nitrogen 
removal. The potential aim is to deepen understanding the mechanisms of the removal of nitrogen in biofiltration system, and assist in improving their design, and ultimately improve their ability to adapt to environmental changes and respond to natural disasters positively.

\section{New issues of nitrogen control in bioretention technology}

Researches over the past decade have shown that for many pollutants, such as suspended solids, nutrients, hydrocarbons, and heavy metals, the load of bioretention effluent was low (LeFevre et al., 2014). Nonetheless, many design questions persist for this practice to achieve the permanency of pollutants removal, because removal performance of pollutants is highly variable and dependent on a range of factors including inflow pollution concentrations and environmental factors, especially for 10-years usage bioretention system (Lucke and Nichols, 2015). Few studies consider the long-term performance but focus on simple pollutant removal. In fact, when the removal of pollutants in stromwater is temporary retention, many processes within bioretention system may be better described as attenuation. And the pollutants will be at some point released, either in its original or transformed state. Nitrogen in stromwater is a critical pollutant, which can lead to the eutrophication of downstream waters. There are two pathways for nitrogen removal - temporary immobilization or permanent removal in gaseous form through transformation and cycling processes. Hence, the fate of nitrogen between temporary and permanent removal pathways is fundamental to long-time performance of nitrogen removal for bioretention. While nitrogen biogeochemical processes have been characterized across wide natural and engineered environments, they have not been explicitly quantified in bioretention system with the unique features including frequent alternating rewet and dry cycles, exposure in extreme weathers, and specific engineered structures different from other ecosystems. This knowledge gap of nitrogen permanent control for bioretention leaves the long-term efficiency of nitrogen removal open to question. Some issues of nitrogen processes for bioretention under uncertain rainfall conditions we must work out were proposed in the review, and these problems have constrained the potential for future design improvements in nitrogen removal.

\section{The intermittent wetting and drying conditions of bioretention system are multiplicity and randomness}

Depending on climate change, drought, flooding and human activities, bioretention system will undergo a frequent alternating rewet and dry process. Drying-rewetting cycle has an essential influence on the transfer and transformation of nitrogen (Tan et al., 2012; Payne et al., 2014c). Due to the uncertain feature of rainfall, the intensity and frequency of drying-rewetting alternation will vary. The cycle of wet and dry depends on precipitation intensity and patterns, and results in multiplicity (including drought 
exposure, continuous flooding, constant wetting, or repeated rewetting-drying alternation) and high randomness for intermittent wetting and drying conditions. At present, the nitrogen removal characteristics of the bioretention system mainly focus on the simulation of a single rewetting-drying alternative condition. Results of these studies cannot adapt to the natural cycle of drying and rewetting caused by climate changes, and the bioretention facilities may not be able to meet the desired functional goals during operation in practice.

\section{Extreme weather changes the nitrogen process in the bioretention system}

In recent years, the frequently occurring extreme events (including frequent droughts, long-term continuous rainfall, etc.) also warn us that we need to explore and predict the possible changes in the process of nitrogen migration and transformation, to improve the adaptive ability of bioretention system to climate change (Hathaway et al., 2014; Wang et al., 2016). Great modified in the water cycle (e.g. evaporation and rainfall) will affect the intensity and frequency of rewetting and drying alternation cycles, thus affecting plant traits and soil microbial communities and its involved physiological and biochemical processes (Pesaro et al., 2004; Sheik et al., 2011; Evans and Wallenstein, 2012). This has led to some new changes in the role of multi-media (i.e. plant-soil-microbes) on nitrogen.

\section{Bioretention systems differ from other ecosystems characterized by drying-rewetting alternations}

Nitrogen leaching in bioretention systems has a commonality with other ecosystems, such as soils (including hydro-fluctuation belts) and wetlands characterized by alternating dryness and wetness (Gordon et al., 2008; Tan et al., 2012), but it has its individual specificity. Characteristics with rewetting and drying alternation of the lined bioretention facilities are utterly dependent on meteorological conditions and highly random. A lined bioretention system is different from the ecosystem connected to the water through hydrological processes. The path of nitrogen transport is not affected by the seasonal water level fluctuation but is only driven by surface runoff over a short term. As a stormwater treatment facility, plant selection, and its diversity are also different from wetland systems, resulting in a significant change in rhizosphere microbial community (Garbeva et al., 2008). Besides, the initial organic matter in bioretention facilities mainly dominates with engineering-grade sands, and its concentration is very low (Payne et al., 2015), which is different from a high carbon substance in sediments of other ecosystems. These particularities will significantly change the timing and location of nitrogen transfer and transformation in the bioretention system. Therefore, relevant research results and conclusions might not be wholly transferable to the systems. 


\section{Current researches of nitrogen process in bioretention system}

\section{Influence of variable wetting and drying regimes on nitrogen process}

After the nitrogen in surficial runoff enters into the bioretention system, it undergoes a range of complex biogeochemical processes. The key pathways for nitrogen removal most likely to occur within biofilters are illustrated in Figure 1. Incoming nitrogen of the system primarily comprise inorganic and organic compounds. Immobilization (or uptake) by plants and microbes is the initial fate to incoming inorganic nitrogen through biotic processes. Following conversion to a range of organic compounds within the living biomass, nitrogen is released back to the soil through detritus release, exudation, or organism death. Dissolved organic nitrogen (input or released within system) may occur mineralization (or ammonification) to release simpler and more accessible nutrient forms (such as ammonium) through the microbial decomposition processes, and released ammonium may be rapidly re-uptake by plants and microbial biomass. Alternative fates of inorganic nitrogen within a bioretention system include a series of transformation processes. $\mathrm{NH}_{4}-\mathrm{N}$ may be oxidized to $\mathrm{NO}_{3}-\mathrm{N}$ via the process of nitrification under aerobic conditions, and then $\mathrm{NO}_{3}-\mathrm{N}$ can be converted into gaseous nitrogen forms $\left(\mathrm{N}_{2} \mathrm{O}, \mathrm{N}_{2}\right)$ through the process of denitrification under submerged (anoxic) zone of biofilers. Other potential processes include the microbial conversion of $\mathrm{NO}_{3}-\mathrm{N}$ to $\mathrm{NH}_{4}-\mathrm{N}$ in the dissimilatory nitrate reduction to ammonium (DNRA) process (Silver et al., 2001), which acts to retain nitrogen within the system. Abiotic processes include the interaction of $\mathrm{NH}_{4}-\mathrm{N}$ with mineral or organic particles through adsorption, chelation, and isomorphic substitution reactions. Therefore, the system can retain nitrogen via abiotic fixation and assimilation to temporary removal of nitrogen, and it also can export in gaseous forms through denitrification to achieve a permanent removal. But it is noteworthy that transformed nutrients can leach from system with effluent. During these processes, nitrogen gradually stores and attenuates, and biogeochemical process of nitrogen is driven by environmental factors (Payne et al., 2014c). The complex processes of nitrogen variation are related to multi-media involved plant, soil, water, and microbial. For example, soil moisture regulates the process of nitrogen transportation and transformation in multiple pathways, such as system connectivity, matrix migration, biological function, and adjusting chemical conditions. There is a remarkable difference between lined bioretention facility and other ecosystems. When bioretention is lined away from native soil, the uncertain multiple rewetting-drying alternations can directly influence multiple media on the process of nitrogen migration and transformation. The bioretention system changes the intrinsic nitrogen cycle mechanism and its corresponding output pathway of nitrogen to a certain extent, resulting in nitrogen leaching. Therein, drought exposure causes significant changes in soil moisture at different spatial and temporal scale, which can promote the coupling of nitrification and denitrification (Wilson and Baldwin, 2008; Minett et al., 2013). However, drought will affect the movement of rhizosphere microorganisms and the growth of plant roots if the dry period is too long. Prolonged 
drought even promotes the occurrence of preferential flow in the subsequent rewetting process, resulting in a change of nitrogen migration pathway. At the same time, dry soils will also promote the release of nitrogen under re-humidification, and emission amount is almost logarithmic to antecedent drying days (Hatt et al., 2007; Payne et al., 2014c). In addition, the hydrodynamic processes formed in different wet/dry schemes during/after rainfall can be regarded as a selection pressure for the microbial community composition. It also drives the change of plant root system configuration to affect plant growth and its metabolic function. And in turn, plant activities alter soil oxygen-enrichment capacity and dry-wet cycles. Ultimately, plant, soil together with water drive the occurrence, distribution, and connectivity of nitrogen transformation (Hinsinger et al., 2009; Manka et al., 2016), and makes this process highly complex.

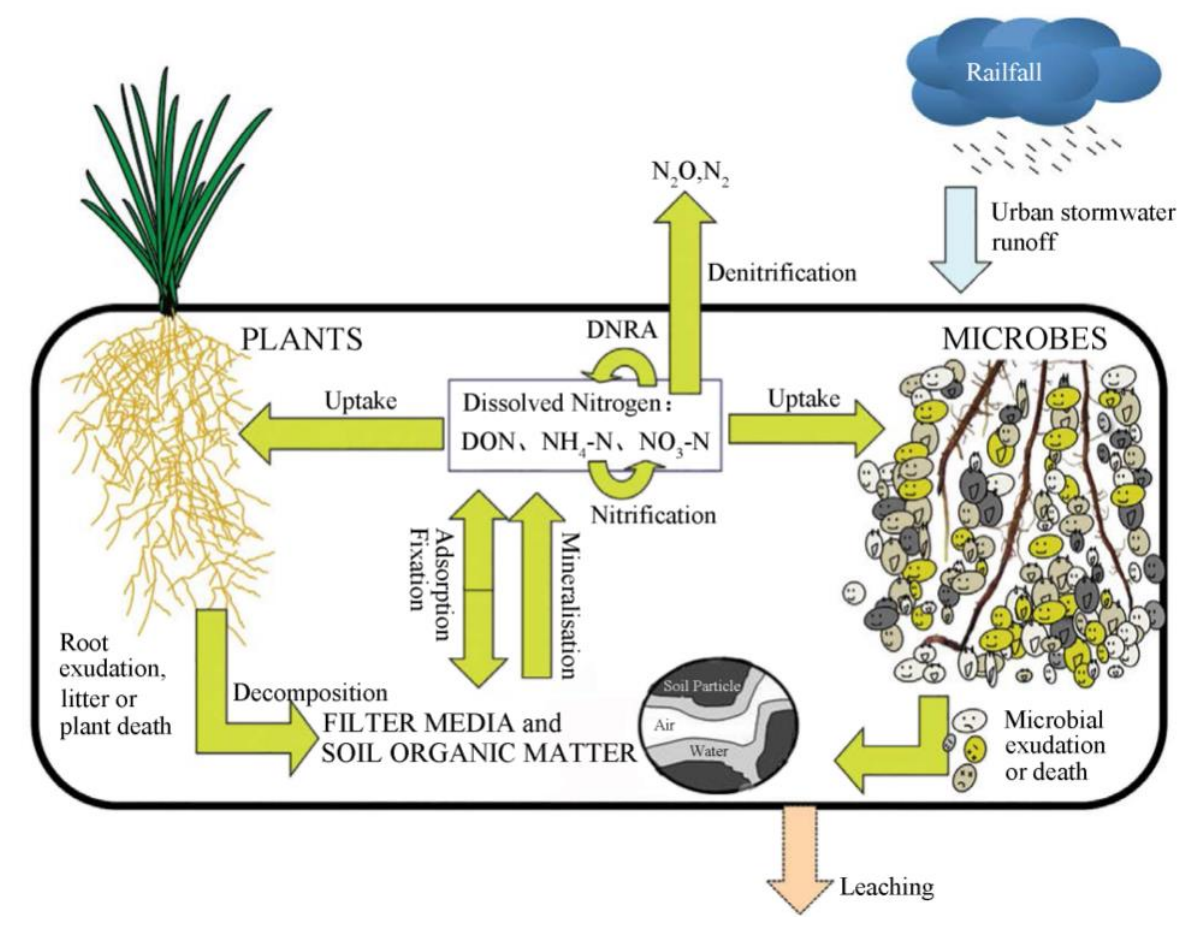

Figure 1. Nitrogen cycling in bioretention system. DNRA: Dissimilatory nitrate reduction to ammonium; DON: dissolved organic nitrogen (adapted from (Payne et al. 2014c, Payne et al. 2015), with permission)

\section{Characterization of nitrogen processes at different spatial and temporal scales}

At present, scholars have conducted extensive and in-deep studies on the nitrogen removal characteristics of biofiltration systems from functional plant species screening (Read et al., 2008; Zinger et al., 2013; Payne et al., 2014b; Wang et al., 2017; Wu et al., 2017; Shrestha et al., 2018), filter media composition (Hsieh and Davis, 2005; Glaister et al., 2014; Wang et al., 2017; Shrestha et al., 2018), and optimization design (Davis et al., 2009; Zinger et al., 2013; Glaister et al., 2017; Wang et al., 2018), and have achieved a 
series of significant research results. And these studies also promoted the development of bioretention technology. However, previous studies basically adopted a simple "black box" approach, which mainly focused on the cumulative mass reduction of nutrients or plant accumulation, and these static studies mostly last a short-term period. And in practice, the experiment is often simplified to an equivalent simulation of a single drywet alternation, in which adopted a single and constant dry-wet alternating frequency based on typical annual rainfall characteristics. These studies fail to fully reveal the nitrogen retention and transformation from the point of the intrinsic development and succession of the ecosystem driven by hydrology of multiple dry/wet schemes. Researchers have gradually regarded a variational hydrological characteristic caused by alternating wetting and drying as a significant influencing factor for nitrogen retention. However, studies mainly focused on the effects of intermittent wetting and drying conditions formed during different antecedent drying periods on nitrogen removal performance; and the results limited to the analysis of nitrogen forms during the wetting period. The previous results did not quantitatively reveal the evolution, migration, and transformation of nitrogen in biogeochemical processes, which was driven by multiple alternating wetting and drying alternations from different spatial and temporal scales (Hatt et al., 2007; Cho et al., 2011; Payne et al., 2014a; Manka et al., 2016; Subramaniam et al., 2016; Tang and $\mathrm{Li}, 2016$ ). In order to improve the removal rate of $\mathrm{NO}_{3}-\mathrm{N}$, a submerged layer of internal water storage is often created using an upturned elbow in a lined bioretention facility to enhance denitrification (Zinger et al., 2013). Nonetheless, the equilibrium relationship between nitrification and denitrification rate also affects the concentration of $\mathrm{NH}_{4}-\mathrm{N}$ and $\mathrm{NO}_{3}-\mathrm{N}$ in the effluent (Randall and Bradford, 2013). Furthermore, a study found that even if the denitrification layer was optimized with an embedded carbon source, setting an appropriate height of submerged layer and other measures, it still cannot achieve a continuous and stable removal of $\mathrm{NO}_{3}-\mathrm{N}$ (LeFevre et al., 2014). Barron et al. (2019) confirmed that the nitrogen removal performance of the best facility (Cares appressa as the dominant plant species) will also appear to a decrease of nitrogen removal rate and then result in leaching when a current best design practice has experienced an extended dry period, as shown in Figure 2. Authors' subsequent research also found that switching water sources (stormwater or greywater) was still vulnerable to leaching again in the initial stage. For example, when the influent of bioretention facility switched from a stormwater source to a greywater source, the nitrogen removal rate decreased from $73 \%$ to $62 \%$, and a significant nitrogen leaching phenomenon occurred. These results confirm that an optimal design study of biofilters conducted under controllable factors cannot achieve expected goals under uncertain meteorological conditions. Despite the fact that setting of the submerged layer in an optimal design can alleviate the adverse effect of water evaporation on plants and microorganisms during dry period. A study found that the bioretention system with submerged layer could reduce the soil moisture content to less than $5 \%$ after 5 weeks of drought, resulting in soil suffering the most disastrous drought, which severely affected 
plant and microbial activity (Blecken et al., 2009). Consequently, the design of bioretention system for single rewetting and drying condition cannot adapt actual rainfall in practice.

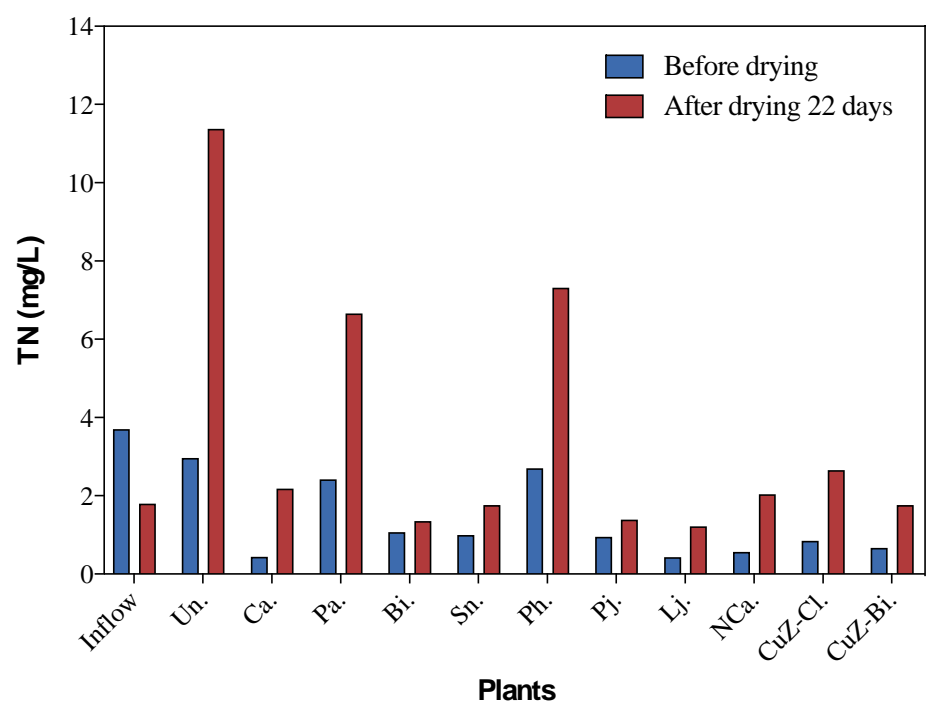

Figure 2. Nitrogen removal in dual-mode stormwater-greywater biofilters after long drying period. Species abbreviations: Un., Un-vegetated; Ca., Cares appressa; Pa., Phragmites australis; Bi., Boston ivy; Sn., Strelitzia Nicolai; Ph., Phormiurn; Pj., Pandorea jasminoides; Lj., Lonicera japonica; NCa., Nil Carex appressa; CuZ-Cl., Canna lilies with anti-microbial $\mathrm{CuZ}$ in the topsoil; CuZ-Bi., Boston ivy with anti-microbial CuZ in the topsoil (data from Barron et al., 2019)

In a bioretention system, which composed of different plants and soil matrix, the interaction process between nitrogen and environmental factors is complicated. Together with uncertain dry-wet alternating conditions, plant holding, microbial nitrification, denitrification, soil adsorption, and end products of nitrogen all have considerable uncertainty. While it is difficult to reflect the behavior and fate of nitrogen in bioretention system using a single research technique and oversimplified method, and exiting studies remain in a qualitative analysis of nitrogen conversion processes. Although a few studies have specialized in the behavior and fate of nitrogen in bioretention systems ( $\mathrm{Li}$ and Davis, 2014; Payne et al., 2014b), they have not elucidated theoretically why did nitrogen leaching from systems, and lacked quantitative research on the microscopic conversion of nitrogen under variable wetting and drying regimes. The limitations of existing studies on bioretention technology have restricted the possibility of its future design improvements, and it also will affect the reliability of long-term performance, particularly its adaptability to extreme weather conditions. 


\section{Nitrogen partitioning and transport in multi-media under different wetting and drying regimes}

Plant immobilization and microbial nitrification - denitrification are considered to be the two primary approaches for the fate of nitrogen in the hydro-fluctuation belt ecosystem up till now (Schade et al., 2002; Hefting et al., 2005), in which, the contribution of denitrification to $\mathrm{NO}_{3}-\mathrm{N}$ can reach $30 \%$ to $100 \%$. A study has confirmed that the contribution rate of denitrification in bioretention system was not more than $10 \%$ through isotopic tracer technology, while the contribution rate of the efficient functional plant to $\mathrm{NO}_{3}-\mathrm{N}$ removal reached high than 90\% (Payne et al., 2014a). This result is entirely different with the observed results in wetland simulation tests, which showed the relative contribution of nitrogen assimilated by plants was $1.9 \%$ to $71 \%$ (Koottatep and Polprasert, 1997; Hefting et al., 2005; Langergraber, 2005). It should be noted that wetlands are permanently wet systems, while biofiltration's dry weather treatment processes are crucial for their performance (Hatt et al., 2009). This makes their selection of plants very different (Read et al., 2008), and thus a significant difference in the nitrogen immobilization of plants between them. However, this study cannot fully trace out the fate and pathway of nitrogen because of the only two-month duration, nor did take the impact of environmental factors caused by uncertain dry/wet schemes into account. Plant fixation potential can change gradually and even disappear with the vegetation succession. Vegetation succession can regulate the contact of underground runoff with plant roots and soil particles, affect the metabolic intensity of nitrogen-functional microbes (Hefting et al., 2005), and then promote soil to keep a higher organic substance in a considerable time (Dosskey et al., 2010). Ultimately, organic matter rich in soil particle enhances metabolic activity and diversity of rhizosphere microbes (Zhang et al., 2010). The diversity of vegetation in bioretention system is relatively single and with landscape characteristics. Besides, plant traits are susceptible to seasonal and dry-wet alternations, and they are also different from the wetland plants. Therefore, whether the succession of plant traits in bioretention system under different dry-wet cycles will promote a formation of organic matter pools in low-carbon soils and then affect microbial community structure, to address this question, knowledge transfer needs to be done from other soil-water ecosystems such as hydro-fluctuation belts or wetlands.

Due to the limitations of single research techniques, instruments and methods, even in the widely studied ecosystems such as the riparian belts and wetlands, the researchers focusing on transformation and fate of nitrogen cannot fundamentally solve the quantitative characterization in nitrogen transformation (Groffman et al., 2002; de Vries, 2003; Zhao et al., 2015; Yang et al., 2016). In recent years, the ${ }^{15} \mathrm{~N}$ isotope tracer technology, stable isotope probe (SIP) technology, and gas quantification technology have been put forward to comparatively study the components and contents of nitrogen involved in plant uptake, metabolism, microbial assimilation, transformation (nitrification and denitrification), soil absorption, and other biochemical processes from 
multi-level and multi-angle views (Ashkenas et al., 2004; Epstein et al., 2012; Charteris et al., 2016; Cui et al., 2017). And these techniques are widely accepted to be a practical approach for accurately quantifying the migration and transformation of nitrogen in the multi-media ecosystem under alternating wetting and drying environments (Morse and Bernhardt, 2013; Payne et al., 2014a; Oburger and Schmidt, 2016), which can provide a powerful technical tool for the quantitative contribution of multi-media to nitrogen process in bioretention system.

\section{Limitations of nitrogen process research in bioretention systems}

The transformation process and fate of nitrogen in bioretention systems are more complex under climate change, and which are driven by many factors such as hydrological environment, climate, plant succession, soil properties, etc. Almost recent studies focused on the monitoring analysis of the difference between nitrogen speciation of inflow and outflow under different macroscopic habitats. It is not able to meet the studying needs on system design optimization, environmental driving mechanism of nitrogen behavior and dynamic mechanism model. Therefore, some critical scientific issues still lack of more explicit answers and await a further investigation. These issues include:

Firstly, the actual contribution of multi-media to fate and transport of nitrogen is still unclear, and its response to changes of environmental factors induced by soil hydrodynamic remains to be explored.

In recent studies on nitrogen fate of bioretention systems, the contribution of multimedia to exogenous imported nitrogen has been primary understood (Payne et al., 2014a), but coupling response studies have not been conducted with changes in environmental factors. A consensus has been basically reached in the academic community. It is widely accepted that hydrological regime caused by surficial runoff can significantly affect the soil water content and its dynamics in bioretention facilities, and then drive the succession of plant root system configuration characteristics. Meanwhile, it can change the oxygen dynamics in soil through root induction, resulting in a spatial heterogeneity with nonrhizosphere soils, and affect a spatial distribution of functional microbes in the rhizosphere. The rhizosphere environment determines the storage and migration processes of nutrients and water, thus regulating the nitrogen of plant uptake and immobilization (Hinsinger et al., 2009; Neuschütz and Greger, 2009). Consequently, these processes have an appreciable impact on nitrogen removal capacity of biofiltration system (Read et al., 2010). A rewetting process can also change soil structure by dissipating soil aggregates due to soil particles expansion and pressure generated by gas retention during wetting (Arias et al., 2005), ultimately resulting in a remarkable effect on plant and microbial functions (Payne et al., 2014c). However, these conclusions can only be used for the qualitative analysis of nitrogen behavior, and they are unclearly explained for the quantitative response relationship between multi-media contribution 
and environmental factors change. In particular, it has remained unknown precisely what the source of nitrogen leaching in dry-wet cycles.

Secondly, the analysis of the coupling relationship between functional bacterial community structure and nitrogen process under soil water stress is absence, and the nitrogen metabolism characteristics of functional microbes under different wet-dry cycles are still unidentified.

The environmental behavior of nitrogen in bioretention systems involves many biochemical processes, but recent studies on the migration and transformation of nitrogen in bioretention systems mainly focus on quantitative determination of its input and output forms, qualitative analysis of transformation pathways, and overall effect on macroscopic habitats. Only a few researchers have focused on the spatial and temporal distribution characteristics of nitrogen functional microbial community in wet periods (Chen et al., 2013). There is still a lack of systematic research on the micro-ecological mechanism of nitrogen behavior in the bioretention system during dry-wet alternations. Studies have confirmed that nitrogen leaching from air-dried soils after rewetting mainly comes from the microbial hydrolysis in the drying period or the release of $\mathrm{NO}_{3}-\mathrm{N}$ stored in the soil, while $\mathrm{NH}_{4}-\mathrm{N}$ will accumulate during the drought and then participate in the subsequent rewetting processes. Consequently, it can safely conclude that nitrogen leaching is a comprehensive result of the synergistic metabolism of various nitrogen-metabolizing bacteria in the soil, and this process is closely related to microbial community structure and functional species. Above all, there is an interaction between nitrogen transport and transformation. If only the temporal and spatial distribution characteristics of the microbial population in the wet period are studied, it is evident that the microscopic mechanism of nitrogen transport and transformation in the multi-media cannot be indeed reflected. While the natural wet/dry alternations caused by meteorological changes positively will affect the ecological environment in biofiltration system, making the species and community structure of nitrogen metabolism bacteria more sophisticated.

\section{Conclusions}

The current study on the contribution of multi-media to the transformation and fate of nitrogen in bioretention system has not been lucubrated, and there are still many problems need to be solved. The review of papers and reports suggest that the multiple rewetting and drying alternations in biorentention systems are the primary objective factors of nitrogen transport and fate without regard to the pulse of nutrient input, which affect or drive plant root system configuration, soil traits, and other habitat factors, and regulate the contribution of multi-media to nitrogen transport and fate, ultimately resulting in a nitrogen leaching.

Further fundamental studies focusing on nitrogen distribution characteristics and its source-sink, plant root architecture, soil properties, and microbial flora formation should be carried out, in order to: 1) clarify the contribution of multi-media to nitrogen transport 
and fate under multiple rewetting and drying alternations, 2) reveal the coupling relationship between functional microbial communities and nitrogen conversion path and metabolic flux, 3) explain the nitrogen leaching mechanism in biorentention systems, and 4) assess nitrogen leaching potential. Continued research should lead to refinement of bioretention design and improved performance. In particular, understanding on nitrogen processes within bioretention system can provide a theoretical basis for design optimization of nitrogen removal characteristics, dynamic mechanism model of nitrogen processes and other subsequent studies.

Acknowledgments. The authors wish to acknowledge the financial from Natural Science Foundation of China (NSFC) (Grant No. 51709024), Basic Science and Frontier Technology Research Program of Chongqing Science and Technology Commission (Grant No. cstc2017jcyjAX0292), Chongqing Residual Innovation Program Funding Project (Grant No. cx2017065), Chongqing Research Innovation Project of Graduate Students (Grant No. CYS17200 and CYS18219), and Science and Technology Research Program of Chongqing Municipal Education Commission (Grant No. KJ1705140). And the authors would also like to thank three reviewers whose review greatly improved this manuscript.

\section{REFERENCES}

[1] Ahiablame, L. M., Engel, B. A., Chaubey, I. (2012): Effectiveness of low impact development practices: Literature review and suggestions for future research. - Water, Air, \& Soil Pollution 223(7): 4253-4273.

[2] Andoh, R. Y. G., Declerck, C. (1997): A cost effective approach to stormwater management? Source control and distributed storage. - Water Science and Technology 36(8-9): 307-311.

[3] Arias, M., González-Pérez, J., González-Vila, F. J., Ball, A. (2005): Soil health - A new challenge for microbiologists and chemists. - International Microbiology 8(1): 13-21.

[4] Ashkenas, L., Johnson, S., Gregory, S., Tank, J. L., Wollheim, W. M. (2004): A stable isotope tracer study of nitrogen uptake and transformation in an old-growth forest stream. - Ecology 85(6): 1725-1739.

[5] Barron, N. J., Deletic, A., Jung, J., Fowdar, H., Chen, Y., Hatt, B. E. (2019): Dual-mode stormwater-greywater biofilters: The impact of alternating water sources on treatment performance. - Water Research 159: 521-537.

[6] Blecken, G. T., Zinger, Y., Deletic, A., Fletcher, T. D., Viklander, M. (2009): Influence of intermittent wetting and drying conditions on heavy metal removal by stormwater biofilters. - Water Resarch 43(18): 4590-4598.

[7] Blecken, G. T., Zinger, Y., Deletić, A., Fletcher, T. D., Hedström, A., Viklander, M. (2010): Laboratory study on stormwater biofiltration: Nutrient and sediment removal in cold temperatures. - Journal of Hydrology 394(3-4): 507-514.

[8] Brown, R. A., Birgand, F., Hunt, W. F. (2013): Analysis of consecutive events for nutrient and sediment treatment in field-monitored bioretention cells. - Water, Air, \& Soil Pollution 224(6): 1581.

[9] Chahal, M. K., Shi, Z., Flury, M. (2016): Nutrient leaching and copper speciation in compost-amended bioretention systems. - Science of the Total Environment 556: 302-309.

[10] Charteris, A. F., Knowles, T. D. J., Michaelides, K., Evershed, R. P. (2016): Compoundspecific amino acid $15 \mathrm{~N}$ stable isotope probing of nitrogen assimilation by the soil microbial biomass using gas chromatography/combustion/isotope ratio mass spectrometry. - Rapid Communications in Mass Spectrometry 30(16): 1846-1856. 
[11] Chen, X., Peltier, E., Sturm, B. S. M., Young, C. B. (2013): Nitrogen removal and nitrifying and denitrifying bacteria quantification in a stormwater bioretention system. - Water Research 47(4): 1691-1700.

[12] Cho, K.-W., Yoon, M.-H., Song, K.-G., Ahn, K.-H. (2011): The effects of antecedent dry days on the nitrogen removal in layered soil infiltration systems for storm run-off control. - Environmental Technology 32(7-8): 747-755.

[13] Cui, L., Kai, Y., Zhou, G., Huang, W., Zhu, Y. (2017): Surface-enhanced raman spectroscopy combined with stable isotope probing to monitor nitrogen assimilation at both bulk and single-sell level. - Analytical Chemistry 89(11): 5793-5800.

[14] Davis, A. P., Hunt, W. F., Traver, R. G., Clar, M. (2009): Bioretention technology: Overview of current practice and future needs. - Journal of Environmental Engineering 135(3): 109-117.

[15] Davis, A. P., Traver, R. G., Hunt, W. F., Lee, R., Brown, R. A., Olszewski, J. M. (2012): Hydrologic performance of bioretention storm-water control measures. - Journal of Hydrologic Engineering 17(5): 604-614.

[16] de Vries, W. (2003): Uncertainties in the fate of nitrogen II: A quantitative assessment of the uncertainties in major nitrogen fluxes in the Netherlands. - Nutrient Cycling in Agroecosystems 66(1): 71-102.

[17] Debusk, K. M., Wynn Thompson, T. (2011): Storm-water bioretention for runoff quality and quantity mitigation. - Journal of Environmental Engineering 137(9): 800-808.

[18] Dosskey, M. G., Vidon, P., Gurwick, N. P., Allan, C. J., Duval, T. P., Lowrance, R. (2010): The role of riparian vegetation in protecting and improving chemical water quality in streams. - Journal of the American Water Resources Association 46(2): 261-277.

[19] Epstein, D. M., Wurtsbaugh, W. A., Baker, M. A. (2012): Nitrogen partitioning and transport through a subalpine lake measured with an isotope tracer. - Limnology and Oceanography 57(5): 1503-1516.

[20] Evans, S. E., Wallenstein, M. D. (2012): Soil microbial community response to drying and rewetting stress: Does historical precipitation regime matter? - Biogeochemistry 109(1): 101-116.

[21] Fletcher, T., Vietz, G., Walsh, C. J. (2014): Protection of stream ecosystems from urban stormwater runoff : The multiple benefits of an ecohydrological approach. - Progress in Physical Geography 38(5): 543-555.

[22] Garbeva, P., van Elsas, J. D., van Veen, J. A. (2008): Rhizosphere microbial community and its response to plant species and soil history. - Plant and Soil 302(1): 19-32.

[23] Géhéniau, N., Fuamba, M., Mahaut, V., Gendron, M. R., Dugué, M. (2014): Monitoring of a rain garden in cold climate: case study of a parking lot near Montréal. - Journal of Irrigation and Drainage Engineering 141(6): 04014073.

[24] Glaister, B. J., Fletcher, T. D., Cook, P. L., Hatt, B. E. (2014): Co-optimisation of phosphorus and nitrogen removal in stormwater biofilters: the role of filter media, vegetation and saturated zone. - Water Science and Technology 69(9): 1961-1969.

[25] Glaister, B. J., Fletcher, T. D., Cook, P. L. M., Hatt, B. E. (2017): Interactions between design, plant growth and the treatment performance of stormwater biofilters. - Ecological Engineering 105: 21-31.

[26] Gordon, H., Haygarth, P. M., Bardgett, R. D. (2008): Drying and rewetting effects on soil microbial community composition and nutrient leaching. - Soil Biology and Biochemistry 40(2): 302-311.

[27] Groffman, P. M., Boulware, N. J., Zipperer, W. C., Pouyat, R. V., Band, L. E., Colosimo, M. F. (2002): Soil nitrogen cycle processes in urban riparian zones. - Environmental Science \& Technology 36(21): 4547-4552.

[28] Hathaway, J. M., Brown, R. A., Fu, J. S., Hunt, W. F. (2014): Bioretention function under climate change scenarios in North Carolina, USA. - Journal of Hydrology 519: 503-511. 
[29] Hatt, B. E., Fletcher, T. D., Deletic, A. (2007): Hydraulic and pollutant removal performance of stormwater filters under variable wetting and drying regimes. - Water Science \& Technology 56(12): 11-19.

[30] Hatt, B. E., Fletcher, T. D., Deletic, A. (2008): Hydraulic and pollutant removal performance of fine media stormwater filtration systems. - Environmental Science \& Technology 42(7): 2535-2541.

[31] Hatt, B. E., Fletcher, T. D., Deletic, A. (2009): Hydrologic and pollutant removal performance of stormwater biofiltration systems at the field scale. - Journal of Hydrology 365(3-4): 310-321.

[32] Hefting, M. M., Clement, J.-C., Bienkowski, P., Dowrick, D., Guenat, C., Butturini, A., Topa, S., Pinay, G., Verhoeven, J. T. A. (2005): The role of vegetation and litter in the nitrogen dynamics of riparian buffer zones in Europe. - Ecological Engineering 24(5): 465482.

[33] Hinsinger, P., Bengough, A. G., Vetterlein, D., Young, I. M. (2009): Rhizosphere: Biophysics, biogeochemistry and ecological relevance. - Plant and Soil 321(1-2): 117-152.

[34] Hsieh, C.-H., Davis, A. P. (2005): Evaluation and optimization of bioretention media for treatment of urban storm water runoff. - Journal of Environmental Engineering 131(11): 1521-1531.

[35] Hunt, W. F., Smith, J. T., Jadlocki, S. J., Hathaway, J. M., Eubanks, P. R. (2008): Pollutant removal and peak flow mitigation by a bioretention cell in Urban Charlotte, N.C. - Journal of Environmental Engineering 134(5): 403-408.

[36] Koottatep, T., Polprasert, C. (1997): Role of plant uptake on nitrogen removal in constructed wetlands located in the tropics. - Water Science and Technology 36: 1-8.

[37] Langergraber, G. (2005): The role of plant uptake on the removal of organic matter and nutrients in subsurface flow constructed wetlands: A simulation study. - Water Science and Technology 51(9): 213-223.

[38] Laurenson, G., Laurenson, S., Bolan, N., Beecham, S., Clark, I. (2013): The role of bioretention systems in the treatment of stormwater. - Advances in Agronomy 120: 223274.

[39] LeFevre, G., Paus, K., Natarajan, P., Gulliver, J., Novak, P., Hozalski, R. (2014): Review of dissolved pollutants in urban storm water and their removal and fate in bioretention cells. - Journal of Environmental Engineering 141(1): 1-23.

[40] Li, H., Sharkey, L. J., Hunt, W. F., Davis, A. P. (2009): Mitigation of impervious surface hydrology using bioretention in North Carolina and Maryland. - Journal of Hydrologic Engineering 14(4): 407-415.

[41] Li, L., Davis, A. P. (2014): Urban stormwater runoff nitrogen composition and fate in bioretention systems. - Environmental Science \& Technology 48(6): 3403-3410.

[42] Li, H., Ding, L., Ren, M., Li, C., Wang, H. (2017): Sponge city construction in China: A survey of the challenges and opportunities. - Water 9(9): 594.

[43] Liu, J., Sample, D., Bell, C., Guan, Y. (2014): Review and research needs of bioretention used for the treatment of urban stormwater. - Water 6(4): 1069-1099.

[44] Lucke, T., Nichols, P. W. B. (2015): The pollution removal and stormwater reduction performance of street-side bioretention basins after ten years in operation. - Science of the Total Environment 536: 784-792.

[45] Mangangka, I. R., Liu, A., Egodawatta, P., Goonetilleke, A. (2015): Performance characterisation of a stormwater treatment bioretention basin. - Journal of Environmental Management 150: 173-178.

[46] Manka, B. N., Hathaway, J. M., Tirpak, R. A., He, Q., Hunt, W. F. (2016): Driving forces of effluent nutrient variability in field scale bioretention. - Ecological Engineering 94: 622628. 
[47] McPhillips, L., Goodale, C., Walter, M. T. (2018): Nutrient Leaching and Greenhouse Gas Emissions in Grassed Detention and Bioretention Stormwater Basins. - Journal of Sustainable Water in the Built Environment 4(1): 04017014.

[48] Minett, D. A., Cook, P. L. M., Kessler, A. J., Cavagnaro, T. R. (2013): Root effects on the spatial and temporal dynamics of oxygen in sand-based laboratory-scale constructed biofilters. - Ecological Engineering 58: 414-422.

[49] Mitchell, V. G. (2006): Applying integrated urban water management concepts: A review of Australian experience. - Environmental Management 37(5): 589-605.

[50] Montalto, F., Behr, C., Alfredo, K., Wolf, M., Arye, M., Walsh, M. (2007): Rapid assessment of the cost-effectiveness of low impact development for CSO control. Landscape and Urban Planning 82(3): 117-131.

[51] Morse, J. L., Bernhardt, E. S. (2013): Using ${ }^{15} \mathrm{~N}$ tracers to estimate $\mathrm{N}_{2} \mathrm{O}$ and $\mathrm{N}_{2}$ emissions from nitrification and denitrification in coastal plain wetlands under contrasting land-uses. - Soil Biology and Biochemistry 57: 635-643.

[52] Mullane, J. M., Flury, M., Iqbal, H., Freeze, P. M., Hinman, C., Cogger, C. G., Shi, Z. (2015): Intermittent rainstorms cause pulses of nitrogen, phosphorus, and copper in leachate from compost in bioretention systems. - Science of the Total Environment 537(10): 294-303.

[53] Neuschütz, C., Greger, M. (2009): Ability of various plant species to prevent leakage of N, $\mathrm{P}$, and metals from sewage sludge. - International Journal of Phytoremediation 12(1): 6784.

[54] Oburger, E., Schmidt, H. (2016): New methods to unravel rhizosphere processes. - Trends in Plant Science 21(3): 243-255.

[55] Olang, L. O., Fürst, J. (2011): Effects of land cover change on flood peak discharges and runoff volumes: Model estimates for the Nyando River Basin, Kenya. - Hydrological Processes 25(1): 80-89.

[56] Palhegyi, G. E. (2010): Designing storm-water controls to promote sustainable ecosystems: Science and application. - Journal of Hydrologic Engineering 15(6): 504-511.

[57] Payne, E. G. I., Fletcher, T. D., Russell, D. G., Grace, M. R., Cavagnaro, T. R., Evrard, V., Deletic, A., Hatt, B. E., Cook, P. L. M. (2014a): Temporary storage or permanent removal? The division of nitrogen between biotic assimilation and denitrification in stormwater biofiltration systems. - PLoS One 9(3): e90890.

[58] Payne, E. G. I., Pham, T., Cook, P. L. M., Fletcher, T. D., Hatt, B. E., Deletic, A. (2014b): Biofilter design for effective nitrogen removal from stormwater - Influence of plant species, inflow hydrology and use of a saturated zone. - Water Science and Technology 69(6): 1312-1319.

[59] Payne, E. G. I., Fletcher, T. D., Cook, P. L. M., Deletic, A., Hatt, B. E. (2014c): Processes and Drivers of Nitrogen Removal in Stormwater Biofiltration. - Critical Reviews in Environmental Science and Technology 44(7): 796-846.

[60] Payne, E. G. I., Hatt, B. E., Deletic, A., Dobbie, M. F., McCarthy, D. T., Chandrasena, G. I. (2015): Adoption Guidelines for Stormwater Biofiltration Systems. - Cooperative Research Centre for Water Sensitive Cities, Melbourne, Australia.

[61] Pesaro, M., Nicollier, G., Zeyer, J., Widmer, F. (2004): Impact of soil drying-rewetting stress on microbial communities and activities and on degradation of two crop protection products. - Applied and Environmental Microbiology 70(5): 2577-2587.

[62] Poor, C., Balmes, C., Freudenthaler, M., Martinez, A. (2018): Role of mycelium in bioretention systems: Evaluation of nutrient and metal retention in mycorrhizae-inoculated mesocosms. - Journal of Environmental Engineering 144(6): 04018034.

[63] Qin, H. P., Li, Z. X., Fu, G. (2013): The effects of low impact development on urban flooding under different rainfall characteristics. - Journal of Environmental Management 129: 577-585. 
[64] Randall, M. T., Bradford, A. (2013): Bioretention gardens for improved nutrient removal. - Water Quality Research Journal of Canada 48(4): 372.

[65] Read, J., Wevill, T., Fletcher, T., Deletic, A. (2008): Variation among plant species in pollutant removal from stormwater in biofiltration systems. - Water Research 42(4-5): 893902.

[66] Read, J., Fletcher, T. D., Wevill, T., Deletic, A. (2010): Plant traits that enhance pollutant removal from stormwater in biofiltration systems. - International Journal of Phytoremediation 12(1): 34-53.

[67] Rhea, L., Jarnagin, T., Hogan, D., Loperfido, J. V., Shuster, W. (2015): Effects of urbanization and stormwater control measures on streamflows in the vicinity of Clarksburg, Maryland, USA. - Hydrological Processes 29(20): 4413-4426.

[68] Roy-Poirier, A., Champagne, P., Filion, Y. (2010): Review of bioretention system research and design: Past, present, and future. - Journal of Environmental Engineering 136(9): 878889.

[69] Schade, J., Martí, E., Welter, J., Fisher, S., Grimm, N. (2002): Sources of nitrogen to the riparian zone of a desert stream: Implications for riparian vegetation and nitrogen retention. - Ecosystems 5: 68-79.

[70] Sheik, C. S., Beasley, W. H., Elshahed, M. S., Zhou, X., Luo, Y., Krumholz, L. R. (2011): Effect of warming and drought on grassland microbial communities. - The ISME Journal 5(10): 1692-1700.

[71] Shrestha, P., Hurley, S. E., Wemple, B. C. (2018): Effects of different soil media, vegetation, and hydrologic treatments on nutrient and sediment removal in roadside bioretention systems. - Ecological Engineering 112: 116-131.

[72] Silver, W. J., Herman, D. J., Firestone, M. K. (2001): Dissimilatory nitrate reduction to ammonium in upland tropical forest soils. - Ecology 82(9): 2410-2416.

[73] Subramaniam, D., Mather, P., Russell, S., Rajapakse, J. (2016): Dynamics of nitratenitrogen removal in experimental stormwater biofilters under intermittent wetting and drying. - Journal of Environmental Engineering 142(3): 04015090.

[74] Tan, X., Shao, D., Liu, H., Yang, F., Xiao, C., Yang, H. (2012): Effects of alternate wetting and drying irrigation on percolation and nitrogen leaching in paddy fields. - Paddy and Water Environment 11(1-4): 381-395.

[75] Tang, N. Y., Li, T. (2016): Nitrogen removal by three types of bioretention columns under wetting and drying regimes. - Journal of Central South University 23(2): 324-332.

[76] Trowsdale, S. A., Simcock, R. (2011): Urban stormwater treatment using bioretention. Journal of Hydrology 397(3-4): 167-174.

[77] Walsh, C. J., Roy, A., Feminella, J. W., Cottingham, P., Groffman, P., Morgan II, R. P. (2005): The urban stream syndrome: Current knowledge and the search for a cure. - Journal of the North American Benthological Society 24(3): 706-723.

[78] Wang, M., Zhang, D. Q., Adhityan, A., Ng, W. J., Dong, J. W., Tan, S. K. (2016): Assessing cost-effectiveness of bioretention on stormwater in response to climate change and urbanization for future scenarios. - Journal of Hydrology 543: 423-432.

[79] Wang, S., Lin, X., Yu, H., Wang, Z., Xia, H., An, J., Fan, G. (2017): Nitrogen removal from urban stormwater runoff by stepped bioretention systems. - Ecological Engineering 106: 340-348.

[80] Wang, C., Wang, F., Qin, H., Zeng, X., Li, X., Yu, S.-L. (2018): Effect of saturated zone on nitrogen removal processes in stormwater bioretention systems. - Water 10(2): 162.

[81] Wilson, J., Baldwin, D. (2008): Exploring the 'Birch effect' in reservoir sediments: Influence of inundation history on aerobic nutrient release. - Chemistry and Ecology 24(6): 379-386. 
[82] Wu, J., Cao, X., Zhao, J., Dai, Y., Cui, N., Li, Z., Cheng, S. (2017): Performance of biofilter with a saturated zone for urban stormwater runoff pollution control: Influence of vegetation type and saturation time. - Ecological Engineering 105: 355-361.

[83] Yang, D., Fan, D. Y., Xie, Z. Q., Zhang, A. Y., Xiong, G. M., Zhao, C. M., Xu, W. T. (2016): Research progress on the mechanisms and influence factors of nitrogen retention and transformation in riparian ecosystems. - Chinese Journal of Applied Ecology 27(3): 973-980. (in Chinese).

[84] Zhang, X., Liu, X., Zhang, M., Dahlgren, R. A., Eitzel, M. (2010): A review of vegetated buffers and a meta-analysis of their mitigation efficacy in reducing nonpoint source pollution. - Journal of Environmental Quality 39(1): 76-84.

[85] Zhao, S., Zhou, N., Liu, X. (2015): Occurrence and controls on transport and transformation of nitrogen in riparian zones of Dongting Lake, China. - Environmental Science and Pollution Research International 23(7): 6483-6496.

[86] Zinger, Y., Blecken, G.-T., Fletcher, T. D., Viklander, M., Deletic, A. (2013): Optimising nitrogen removal in existing stormwater biofilters: Benefits and tradeoffs of a retrofitted saturated zone. - Ecological Engineering 51: 75-82. 